\title{
Advanced Placement Scores for Black Male Students from Connecticut, Florida, Maryland, Massachetts, and Texas
}

\author{
Jeanine L. Wilson, ${ }^{1}$ John R. Slate, ${ }^{2}$ George W. Moore, ${ }^{2}$ and Wally Barnes ${ }^{2}$ \\ ${ }^{1}$ Houston Independent School District, Houston, TX 77092, USA \\ ${ }^{2}$ Sam Houston State University, Huntsville, TX 77341, USA \\ Correspondence should be addressed to John R. Slate; profslate@aol.com
}

Received 18 June 2014; Accepted 20 August 2014; Published 31 August 2014

Academic Editor: Leonidas Kyriakides

Copyright (C) 2014 Jeanine L. Wilson et al. This is an open access article distributed under the Creative Commons Attribution License, which permits unrestricted use, distribution, and reproduction in any medium, provided the original work is properly cited.

Differences in student performance were analyzed for Black males in Connecticut, Florida, Maryland, Massachusetts, and Texas on the Advanced Placement English Language and Composition, Calculus AB, Biology, and United States History examinations from the 2001 through the 2012 exam years. All analyses included in the comparisons of overall examination scores and U.S. History examination scores were statistically significant. Of the 48 individual examination comparisons, 26 yielded evidence of a statistically significant difference among the Black male students from the selected states. Massachusetts was the state with the highest percentages of Black male students who achieved an AP score of 4 or 5. Conversely, Texas was the state with the highest percentages of Black male students who failed to achieve an AP score of 4 or 5. Implications for policy regarding advanced placement testing as an avenue for preparing students for college and recommendations for future research are discussed.

\section{Introduction}

With regard to advanced placement (AP) courses, numerous topics have been addressed by educational practitioners. Advanced placement courses are advanced, college-level courses taken by high school students who, upon successful completion of the course and a standardized AP examination, may receive college credit [1]. A review of the relevant literature related to the College Board's AP program, particularly regarding participation among minorities, includes a plethora of topics related to participation, performance, and equity. Noted in a review of current literature regarding the relevance of AP programs were concerns about low participation rates of Black and Hispanic students and low success rates on AP exams [2].

Advanced placement, preadvanced placement, international baccalaureate, and dual credit courses are ways of increasing the college-readiness level of students by virtue of their reputation for encompassing a demanding curriculum that has been regarded on par with college level coursework. The advanced placement program includes a summative assessment in every course, that is, administered each year to evaluate the student's mastery of course objectives. As such, advanced placement examinations have been regarded as a universal measure of the quality of secondary student learning as well as evidence of collaboration between high schools and institutions of higher learning. Moore and Slate [3] noted the efforts of the College Board to broaden the scope of AP through the inclusion of all students who wish to attempt an advanced course by providing capital to support the costs related to the administration of AP examinations.

School districts across the nation have attempted to respond to the call for greater attention toward improving students' preparation for and success in advanced coursework; yet, district leaders continue to struggle with an achievement gap that seems to remain fixed $[1,4]$. As public school leaders seek to find ways of improving Black and Hispanic student participation and academic achievement in the AP program, specific consideration for increasing the participation and achievement among Black males is warranted. Indeed, Education Week [5] described the ideology of an achievement gap as the resulting trends in the academic successes of Black, 
Hispanic, and low-income student groups when compared to the academic successes of White students and students from economically advantaged homes.

Although many Black children are learning and excelling within their communities, Black males are not experiencing the same degree of academic success as their White male peers [6]. In fact, one of the most consistent findings in educational research is the underachievement of Black males at all levels of education [7]. The Schott Foundation for Public Education [8] established that only $41 \%$ of Black men graduated from high school in the United States. Moreover, The College Board [9] reported that young Black and Hispanic males significantly trail behind most of their peers in the context of academic achievement and high school completion. In fact, Black, Hispanic, Native-American, and Asian-American men were outperformed by their female counterparts in each racial grouping by $9 \%, 9 \%, 7 \%$, and $2 \%$, respectively. Furthermore, a disparate low rate of $26 \%$ of Black males, $24 \%$ of Native American and Pacific Islander males, and 18\% of Hispanic males have, at minimum, an associate degree [9].

Investigations into AP course participation among Black and Hispanic students have resulted in viable recommendations for policy and practical change; however, the enrollment rate of Black and Hispanic students across the United States in AP courses is still little more than $50 \%$ of the rate of White students $[2,10,11]$. The divergent enrollment rates among Black, Hispanic, and White students in AP courses remain regardless of the positive correlation between AP course participation and college degree completion. Evidence exists for the value of an increased offering of AP courses to students who attend majority Black and Hispanic schools [12]. The studies conducted to date have included data that have served as discussion points regarding the perils of growing up a Black or Hispanic youth in the United States [13-18]. Moreover, subsequent studies and reports have included data to illustrate the profound problems that Black and Hispanic youth in the United States face regarding participation in rigorous academic programs [19-22]; yet the evidence that the problems facing Black males are more chronic and extreme is astounding $[23,24]$. Therefore, measures to support the academic endeavors of Black males deserve attention, thus the impetus for this study.

\section{Statement of the Problem}

Taking AP courses and demonstrating proficiency on AP exams are the hallmark of scholars. Yet, issues of access and equity, as it relates to Black students, abound. Indeed, the U.S. Department of Education utilized AP data as an indicator of the condition of the American educational system in its Condition of Education Report [25] and the several states expanded AP programs by subsidizing examination fees [26]. Black students are not performing as well as their peers in a variety of areas in academe, and this achievement gap increasingly widens as it relates to academic performance in AP courses $[6,27,28]$. As the number of Black students taking the AP exam steadily increased between 2003 and 2008, Black students fell short of every other ethnic group in the percentage of AP examinees versus the percentage of the population each group represents $[1,9,27,29,30]$. Indeed, a body of literature related to the Black student population in AP courses as a whole exists [31-35]; however, Black males who have taken AP examinations were the specific focus of this study.

Black males continue to face academic challenges. Therefore, The Council of the Great City Schools called for a national effort to eradicate these challenges [6]. Consequently, this study is predicated by the countless initiatives focused upon eradicating the achievement gap between White students and non-White students, particularly in the arena of AP course opportunities $[9,29,36]$ with deeper consideration for Black males.

\section{Purpose of the Study}

The purpose of this study was to analyze the extent to which differences in student performance were present between Black males in Connecticut, Florida, Maryland, Massachusetts, and Texas on selected AP examinations from 2001 through 2012 exam years. Specific AP exams included in this study were the English Language and Composition, Calculus AB, Biology, and United States History. Data from The College Board website were analyzed to determine the overall AP examination performance among Black males in Connecticut, Florida, Maryland, Massachusetts, and Texas between 2001 and 2012. Archival data were obtained from the College Board and were analyzed using inferential statistical procedures to determine the degree to which differences in AP exam performance were present as a function of race and state residency.

\section{Significance of the Study}

The graduating class of 2011 included Black students who accounted for $14.7 \%$ of the overall student population in AP classrooms but only $9 \%$ of the AP exam-taking population. As such, Black students are clearly an underrepresented group in taking AP exams [1]. Moreover, of the Black students who graduated high school in the United States in 2010, 63\% were female, and $37 \%$ were male [30]. When an absence of equity among the population of AP students and exam-takers exists, a segment of the U.S. student population may be devoid of the opportunities an advanced academic career can bring.

The College Board [30] declared that a simple expansion of AP course enrollment is insufficient and reiterated the importance of adequately preparing all middle school and high school students for the rigors of college-level course work. This investigation will provide support for policymaker's needs to move toward a deliberate approach regarding addressing the needs of Black male performance on AP exams. Such an approach may result in a new regard for Black males as scholars and contributors to a larger society. Hargrove et al. [37] confirmed the significance of AP examination scores through their conclusion that the average first-year college grade point averages (GPAs) for 1998 to 2002 cohorts and the average fourth-year college GPAs for 1998 to 2001 cohorts increased as average AP examination grades increased. Furthermore, their investigation led them to the 
discovery that students who possessed average AP examination "grades of 1 earned significantly fewer first- and fourthyear college credits than those who had AP exam grade averages of 2 or above" ([37]; pages 38-39). Hence, examining the AP examination performance between Black males in Connecticut, Florida, Maryland, Massachusetts, and Texas may serve as a springboard for a broader examination into the academic practices ascribed by each of the included states.

The aforementioned states were selected based upon 4 of the included state's position among the top 10 states in the nation where students scored a 3 or higher on an AP exam during their high school years (i.e., Connecticut, Florida, Maryland, and Massachusetts), and the accolades school districts in Texas received from the College Board for their efforts related to increasing AP opportunities and success among students who are typically underserved $[1,10]$. Conversely, the proposed study may yield evidence of an achievement gap between Black males and White males in the included states regardless of the state's position in the top 10 AP standings. Finally, provided this study yields evidence of an achievement gap between Black males in Connecticut, Florida, Maryland, Massachusetts, or Texas, the distinction of a top AP performing state stands to prompt a deeper assessment of the established pedagogical and programmatic measures taken throughout each state. As Ladson-Billings [38] proffered, "at a minimum, schools must provide students with adequate resources to learn and participate fully in the knowledge economy" (p. 311). As such, we believe that access to rigorous curricula in high school prepares Black students for success in college; however, access in and of itself is not enough.

\section{Research Questions}

The following research questions were repeated for each of the years of data available for the states of Connecticut, Florida, Maryland, Massachusetts, and Texas. (a) What is the difference in AP English Language and Composition exam performance of Black males as a function of state residency for the 2001 school year? (b) What is the difference in AP Calculus $\mathrm{AB}$ exam performance of Black males as a function of state residency for the 2001 school year? (c) What is the difference in AP Biology exam performance of Black males as a function of state residency 2001 school year? (d) What is the difference in AP United States History exam performance of Black males as a function of state residency for the 2001 school year? (e) What is the difference in overall AP examination performance of Black males as a function of state residency for the 2001 school year? Following these analyses, the extent to which trends were present in Black male performance for each of these AP exams across the school years was examined.

\section{Method}

6.1. Research Design. To compare the performance on AP examinations between Black male students from Connecticut, Florida, Maryland, Massachusetts, and Texas, a causalcomparative design was selected. According to Johnson and Christensen [39], causal-comparative research includes categorical independent variables and quantitative dependent variables. For the purpose of this study, the categorical independent variables included state of residency and ethnicity due to the fact that such indicators are predetermined and are not subject to being manipulated. The academic performance of Black male students was measured by their scores attained on the following AP exams: AP English Language and Composition, AP Calculus AB, AP Biology, and AP United States History. Accordingly, student outcomes on these exams represented the dependent variables.

6.2. Selection of Participants. For the purpose of this study, archival data related to AP examinations for Black male students in Connecticut, Florida, Maryland, Massachusetts, and Texas between 2001 and 2012 were secured for this research analysis. Connecticut, Florida, Maryland, and Massachusetts were selected as 4 of the 5 focal states of this study due to their position as the topmost states in the nation related to increased percentages of students who scored a 3 or higher on an AP examination between 2001 and 2012 [1]. Furthermore, Texas was included due its position as the second largest state in the United States in relation to AP examinee population and subsequent commendations from the College Board [10] for the efforts of school districts related to increasing equitable AP opportunities and success among high school students. Student performance on the following AP exams was examined: AP English Language and Composition, AP Calculus AB, AP Biology, and AP United States History as well as data related to the overall AP examination performance for Black male students in Connecticut, Florida, Maryland, Massachusetts, and Texas between 2001 and 2012. The AP examinations included were selected in an effort to achieve representation from each of the core content areas; namely, English/Language Arts, Mathematics, Science, and Social Studies.

6.3. Instrumentation. Archival data collected and published on the College Board website [1] were obtained. The College Board gathers data on all participating students in AP exams and thus provides these data on their website for the 2001 through the 2012 school years. Statistics for AP exams were separated by gender and ethnicity, and the overall AP exam performance scores for Black males in the states of Connecticut, Florida, Maryland, Massachusetts, and Texas were analyzed.

6.4. Procedure. Archival data were transmitted via electronic download from the College Board website. The archived data retrieved from the College Board website were all AP examination scores for all participants in Connecticut, Florida, Maryland, Massachusetts, and Texas. Within the downloaded data set, select AP exam scores (i.e., AP Biology, AP English Language and Composition, AP Calculus AB, and AP United States History) for Black males in the selected states for the years 2001 through 2012 were examined. Additionally, all included data were examined to ascertain related trends in the overall examination performance among Black males.

6.5. Data Analysis. A sequence of 5 (state of residency) $\times 2$ (selected AP examination score group) chi-square 
procedures were employed as an appropriate measure for analyzing the relationships between the variables present in the study. The AP examination score groups included two score categories, namely, potential college credit and no potential for college credit. Advanced placement scores of 4 and 5 were included in the potential college credit category. Conversely, the no potential for college credit category were comprised of AP examination scores of 3 or less. Readers should note that this proposed statistical analysis differs from previous analyses of AP exam scores [3, 40-43]. The rationale for analyzing AP exam scores as categories related to the potential for college credit reflects the reality that very few 4 -year institutions provide college credit for a score of 3 . As such, these scores of 3,2 , and 1 constitute a no college credit category. Though not all 4-year institutions currently provide college credit for a 4 or 5 , many such institutions still do, thereby justifying a category of potential for college credit for AP exam scores of 4 or 5 . Pearson chisquare tests were conducted to ascertain the presence of a statistically significant difference between the selected AP exam score distributions as a function of state residency (i.e., Connecticut, Florida, Maryland, Massachusetts, and Texas).

\section{Results}

7.1. Results for AP English Language and Composition. Focused upon in the first research question of this study was a comparison of the AP English Language and Composition exam scores of Black male students in Connecticut, Florida, Maryland, Massachusetts, and Texas, from 2001 through 2012. In 2001, a statistically significant difference was revealed, $\chi^{2}(4)=23.69, P<.001$, Cramer's $V$ of .17, small effect size [44]. Connecticut had the highest percentage (17\%) of Black male students who had AP exam scores that could potentially receive college credit based upon their AP exam score, followed by Maryland (15\%). All other states had less than $10 \%$ of their Black males who earned AP exam scores that could potentially receive college credit.

Of note, over $90 \%$ of Black male students in three of the five states examined in this study received AP scores for which they would not receive college credit. Specifically, 97\% of Black male students in Texas did not achieve AP scores that would enable them to receive college credit, $94 \%$ of Black male students in Massachusetts experienced a negative outcome on the AP English Language and Composition exam, and $93 \%$ of Black male students in Florida achieved a score of 3 or lower on the AP English Language and Composition exam.

In 2002, a statistically significant difference was not revealed, $\chi^{2}(4)=3.67, P=.453$. Maryland had the highest percentage (14\%) of Black male students who could potentially receive college credit based upon their AP exam score, followed by Massachusetts (13\%), Connecticut (10\%), Texas (9\%), and Florida (8\%). Less than $15 \%$ of Black male students in the five states examined in this study received AP scores for which they would receive college credit. In 2003, a statistically significant difference was not present among the data examined, $\chi^{2}(4)=6.61, P=.158$. Connecticut had the highest percentage (12\%) of Black male students who had
AP exam scores that could potentially receive college credit, followed by Massachusetts (11\%), Florida (8\%), Maryland (8\%), and Texas (5\%). Again, less than $15 \%$ of Black male students examined in this study received AP scores for which they would receive college credit.

In 2004, a statistically significant difference was revealed, $\chi^{2}(4)=20.91, P<.001$, Cramer's $V$ of .18 , small effect size [44]. In contrast to previous exam years, Massachusetts had the highest percentage (16\%) of Black male students who had AP exam scores that could potentially receive college credit, followed by Maryland (14\%), Texas (5\%), Florida (9\%), and Connecticut (8\%). During the 2004 school year, over $80 \%$ of Black male students in the five states examined in this study achieved AP scores for which they would not receive college credit.

A statistically significant difference was present for the 2005 exam year, $\chi^{2}(4)=32.71, P<.001$, Cramer's $V$ of .14 , small effect size. Connecticut had the highest percentage (17\%) of Black male students who had AP exam scores that could potentially receive college credit, followed by Maryland (16\%), Florida (7\%), Texas (6\%), and Massachusetts (4\%). Over $80 \%$ of Black male students in four of the five states examined in this study received AP scores that are likely to yield no college credit.

For the 2006 exam year, a statistically significant difference was revealed, $\chi^{2}(4)=28.44, P<.001$, Cramer's $V$ of .12 , small effect size. Connecticut had the highest percentage (14\%) of Black male students who had AP exam scores that could potentially receive college credit, followed by Maryland (11\%), Massachusetts (7\%), Florida (6\%), and Texas (4\%). For the 2006 school year, over $85 \%$ of Black male students in every state examined in this study received AP scores that had the propensity to yield no college credit.

With respect to the 2007 exam year, a statistically significant difference was not revealed at the conventional level of statistical significance, $\chi^{2}(4)=9.22, P=.055$. Connecticut had the highest percentage (15\%) of Black male students who had AP exam scores that could potentially receive college credit, followed by Maryland (12\%), Massachusetts (11\%), Florida (8\%), and Texas (7\%). Conversely, over $85 \%$ of Black male students in the five states examined in this study achieved AP scores for which they would not receive college credit.

Concerning the 2008 exam year, a statistically significant difference was revealed, $\chi^{2}(4)=23.13, P<.001$, Cramer's $V$ of .08 , trivial effect size. Massachusetts had the highest percentage (17\%) of Black male students who had AP exam scores that could potentially receive college credit, followed by Connecticut (12\%), Maryland (11\%), Texas (6\%), and Florida (6\%). However, over $80 \%$ of Black male students in the five states examined in this study received AP scores for which they would not receive college credit. With respect to the 2009 exam year, a statistically significant difference was present, $\chi^{2}(4)=10.88, P=.028$, Cramer's $V$ of .06 , trivial effect size. Connecticut had the highest percentage (17\%) of Black male students who had AP exam scores that could potentially receive college credit, followed by Massachusetts (14\%), Maryland (10\%), Texas (9\%), and Florida 
(8\%). However, over $80 \%$ of Black male students in the five states examined in this for which they would not receive college credit study received AP scores for which they would not receive college credit.

In the 2010 exam year, a statistically significant difference was revealed for the AP English Language and Composition examination, $\chi^{2}(4)=31.59, P<.001$, Cramer's $V$ of .09 , small effect size. Yet again, Massachusetts had the highest percentage $(20 \%)$ of Black male students who had AP exam scores that could potentially receive college credit, followed by Connecticut (15\%), Maryland (11\%), Texas (8\%), and Florida (7\%). However, over $75 \%$ of Black male students in the five states examined in this study received AP scores for which they would not receive college credit.

Concerning the 2011 exam year, a statistically significant difference was not revealed, $\chi^{2}(4)=7.43, P=.115$. As in most of the previous years studied for this examination, Connecticut had the highest percentage (14\%) of Black male students who had AP exam scores that could potentially receive college credit, followed by Maryland (11\%), Massachusetts $(10 \%)$, Texas (9\%), and Florida (7\%). However, over $85 \%$ of Black male students in the five states examined in this study received AP scores for which they would not receive college credit.

Regarding the 2012 exam year, a statistically significant difference was revealed, $\chi^{2}(4)=19.38, P<.001$, Cramer's $V$ of .07 , trivial effect size. Again, Connecticut had the highest percentage (19\%) of Black male students who had AP exam scores that could potentially receive college credit, followed by Massachusetts (17\%), Maryland (12\%), Texas (10\%), and Florida (9\%). However, over $70 \%$ of Black male students in the five states examined in this study received AP scores for which they would not receive college credit.

7.2. Results for AP Calculus AB. Focused upon in the second research question was a comparison of the $\mathrm{AP}$ Calculus $\mathrm{AB}$ exam scores of Black male students in Connecticut, Florida, Maryland, Massachusetts, and Texas, from 2001 through 2012. In 2001, a statistically significant difference was not revealed, $\chi^{2}(4)=2.00, P=.736$. Connecticut had the highest percentage $(23.33 \%)$ of Black male students who had AP exam scores that could potentially receive college credit, followed closely by Massachusetts (22.5\%), Maryland (22\%), Florida $(22.40 \%)$, and Texas (75\%). However, over $75 \%$ of Black male students in the five states examined in this study received AP scores for which they would not receive college credit

In 2002, a statistically significant difference was not revealed, $\chi^{2}(4)=5.24, P=.264$. Massachusetts had the highest percentage $(29 \%)$ of Black male students who had AP exam scores that could potentially receive college credit, followed by Florida (24\%), Maryland (18\%), Texas (18\%), and Connecticut (13\%). However, over $70 \%$ of Black male students in the five states examined in this study received AP scores for which they would not receive college credit.

In 2003, a statistically significant difference was not revealed, $\chi^{2}(4)=8.48, P=.076$. Similar to the previous exam year, Massachusetts had the highest percentage (37\%) of Black male students who had AP exam scores that could potentially receive college credit, followed by Connecticut (30\%), Maryland (24\%), Florida (20\%), and Texas (19\%). However, over $60 \%$ of Black male students in the five states examined in this study received AP scores for which they would not receive college credit. In 2004, a statistically significant difference was not revealed, $\chi^{2}(4)=8.40, P=.078$. Connecticut had the highest percentage (29\%) of Black male students who had AP exam scores that could potentially receive college credit, followed by Massachusetts (28\%), Florida (20\%), Maryland (19\%), and Texas (15\%). However, over $70 \%$ of Black male students in the five states examined in this study received AP scores for which they would not receive college credit. In 2005, a statistically significant difference was not revealed, $\chi^{2}(4)=1.36, P=.851$. Maryland had the highest percentage $(22 \%)$ of Black male students who had AP exam scores that could potentially receive college credit, followed by Massachusetts (19\%), Florida (19\%), Texas (18\%), and Connecticut (15\%). Over $80 \%$ of Black male students in four of the five states examined in this study received AP scores that are likely to yield no college credit.

In 2006, a statistically significant difference was revealed, $\chi^{2}(4)=10.31, P=.038$, Cramer's $V$ of .11 , small effect size. Massachusetts had the highest percentage $(37 \%)$ of Black male students who had AP exam scores that could potentially receive college credit, followed by Connecticut (28\%), Maryland (23\%), Texas (19\%), and Florida (21\%). Over $60 \%$ of Black male students in the states examined in this study received AP scores for which they would not receive college credit. In 2007, a statistically significant difference was not revealed, $\chi^{2}(4)=5.79, P=.215$. Maryland had the highest percentage $(25 \%)$ of Black male students who had AP exam scores that could potentially receive college credit, followed by Massachusetts (23\%), Florida (19\%), Texas (17\%), and Connecticut (14\%). However, over $75 \%$ of Black male students in the five states examined in this study received AP scores for which they would not receive college credit.

In 2008, a statistically significant difference was revealed, $\chi^{2}(4)=10.45, P=.033$, Cramer's $V$ of .09 , trivial effect size. Connecticut had the highest percentage (26\%) of Black male students who had AP exam scores that could potentially receive college credit, followed by Massachusetts (25\%), Maryland (24\%), Texas (19\%), and Florida (15\%). Over $70 \%$ of Black male students in the five states examined in this study received AP scores for which they would not receive college credit. In 2009, a statistically significant difference was not revealed at the conventional level of statistical significance, $\chi^{2}(4)=9.14, P=.058$. Connecticut had the highest percentage $(28 \%)$ of Black male students who had AP exam scores that could potentially receive college credit, followed by Massachusetts (23\%), Maryland (22\%), Florida (19\%), and Texas (15\%). Over $70 \%$ of Black male students in the five states examined in this study received AP scores for which they would not receive college credit.

In 2010, a statistically significant difference was not revealed, $\chi^{2}(4)=7.47, P=.113$. Connecticut had the highest percentage $(25 \%)$ of Black male students who had AP exam scores that could potentially receive college credit, followed by Maryland (17\%), Texas (16\%), Florida (14\%), and 
Massachusetts (12\%). Over $75 \%$ of Black male students in the five states examined in this study received AP scores for which they would not receive college credit. A statistically significant difference was not present for the 2011 exam year, $\chi^{2}(4)=7.54, P=.11$. Connecticut had the highest percentage (27\%) of Black male students who had AP exam scores that could potentially receive college credit, followed by Texas (17\%), Maryland (16\%), Florida (16\%), and Massachusetts (13\%). Again, over $70 \%$ of Black male students in the five states examined in this study received AP scores for which they would not receive college credit. For the 2012 exam year, a statistically significant difference was not revealed, $\chi^{2}(4)$ $=3.86, P=.425$. Massachusetts had the highest percentage (24\%) of Black male students who had AP exam scores that could potentially receive college credit, followed by Maryland (24\%), Texas (22\%), Florida (20\%), and Connecticut (15\%). Again, over $75 \%$ of Black male students in the five states examined in this study received AP scores for which they would not receive college credit.

7.3. Results for AP Biology. The emphasis of the third research question was on comparing the AP Biology exam scores of Black male students in Connecticut, Florida, Maryland, Massachusetts, and Texas, from 2001 through 2012. In 2001, a statistically significant difference was not revealed, $\chi^{2}(4)$ $=7.33, P=.119$. Massachusetts had the highest percentage (28\%) of Black male students who had AP exam scores that could potentially receive college credit, followed Florida (16\%), Maryland (15\%), Connecticut (14\%), and Texas (8\%). Over $70 \%$ of Black male students in the five states examined in this study received AP scores for which they would not receive college credit.

Regarding the 2002 exam year, a statistically significant difference was present, $\chi^{2}(4)=10.00, P=.04$, Cramer's $V$ of .17, small effect size. Massachusetts had the highest percentage $(39 \%)$ of Black male students to achieve an AP exam score that would possibly yield them college credit, followed by Florida (24\%), Maryland (19\%), Connecticut (17\%), and Texas (14\%). Over $75 \%$ of Black male students in four of the five states examined in this study received AP scores for which they would not receive college credit.

Concerning the 2003 exam year, a statistically significant difference was not yielded, $\chi^{2}(4)=0.95, P=.917$. As in prior years, Massachusetts had the highest percentage $(16.13 \%)$ of Black male students who had AP exam scores that could potentially yield college credit, followed closely by Connecticut (15.79\%), Texas (14\%), Florida (13\%), and Maryland (11\%). Over $80 \%$ of Black male students in the five states examined in this study received AP scores for which they would not receive college credit.

For the 2004 exam year, a statistically significant difference was not revealed, $\chi^{2}(4)=3.32, P=.506$. Again, Massachusetts had the highest percentage $(23 \%)$ of Black male students who had AP exam scores that could potentially receive college credit, followed by Maryland (20\%), Florida (15\%), Texas (14\%), and Connecticut (10\%). Over $75 \%$ of Black male students in the five states examined in this study received AP scores for which they would not receive college credit. Regarding the 2005 exam year, a statistically significant difference was not revealed, $\chi^{2}(4)=7.87, P=$ .097 . Connecticut had the highest percentage (39\%) of Black male students who had AP exam scores that could potentially receive college credit, followed by Maryland (17\%), Texas (14\%), and Florida (15\%), and Massachusetts (13\%). Over 80\% of Black male students in four of the five states examined in this study received AP scores that would not yield college credit.

With respect to the 2006 exam year, a statistically significant difference was not present, $\chi^{2}(4)=8.1, P=.088$. Massachusetts had the highest percentage $(24 \%)$ of Black male students who had AP exam scores that could potentially receive college credit, followed by Maryland (18\%), Texas (16\%), Florida (13\%), and Connecticut (5\%). Over $75 \%$ of Black male students in every state examined in this study received AP scores for which they would not receive college credit. Regarding the 2007 exam year, a statistically significant difference was not revealed, $\chi^{2}(4)=8.2, P=.085$. Connecticut had the highest percentage $(41 \%)$ of Black male students who had AP exam scores that could potentially receive college credit, followed by Massachusetts (24\%), Maryland (19\%), Florida (18\%), and Texas (14\%). Over $75 \%$ of Black male students in the 4 out of the 5 states examined in this study received AP scores for which they would not receive college credit.

Concerning the 2008 exam year, a statistically significant difference at the conventional level of statistical significance was not present, $\chi^{2}(4)=9.26, P=.055$. Massachusetts and Texas had the highest percentage $(16 \%)$ of Black male students who had AP exam scores that could potentially receive college credit, followed by Maryland (15\%), Connecticut (10\%), and Florida (8\%). Over $80 \%$ of Black male students in the five states examined in this study received AP scores for which they would not receive college credit. For the 2009 exam year, a statistically significant difference was revealed, $\chi^{2}(4)=11.19, P=.025$, Cramer's $V$ of .11 , small effect size. Connecticut had the highest percentage $28 \%$ of Black male students who had AP exam scores that could potentially receive college credit, followed by Texas (16\%), Maryland (13\%), Florida (12\%), and Massachusetts (6\%). Over $70 \%$ of Black male students in the five states examined in this study received AP scores for which they would not receive college credit.

Regarding the 2010 exam year, a statistically significant difference was not revealed, $\chi^{2}(4)=8.55, P=.073$. Massachusetts had the highest percentage (19\%) of Black male students who had AP exam scores that could potentially receive college credit, followed by Texas (14\%), Connecticut (11\%), Maryland (11\%), and Florida (9\%). Over $80 \%$ of Black male students in the five states examined in this study received AP scores for which they would not receive college credit. For the 2011 exam year, a statistically significant difference was not present, $\chi^{2}(4)=8.64, P=.071$. Connecticut had the highest percentage (19\%) of Black male students who had AP exam scores that could potentially receive college credit, followed by Massachusetts (15\%), Florida (15\%), Maryland (13\%), and Texas (9\%). Over $80 \%$ of Black male students in 
the five states examined in this study received AP scores for which they would not receive college credit.

Concerning the 2012 exam year, a statistically significant difference was yielded, $\chi^{2}(4)=21.37, P<.001$, Cramer's $V$ of .13, small effect size. Connecticut had the highest percentage $(29 \%)$ of Black male students who had AP exam scores that could potentially receive college credit, followed by Massachusetts (25\%), Maryland (14\%), Texas (13\%), and Florida (12\%). Over $70 \%$ of Black male students in the five states examined in this study received AP scores for which they would not receive college credit.

7.4. Results for AP US History. Focused upon in the fourth research question was a comparison of the AP U.S. History exam scores of Black male students in Connecticut, Florida, Maryland, Massachusetts, and Texas, from 2001 through 2012. In 2001, a statistically significant difference was revealed, $\chi^{2}(4)=20.86, P=.003$, Cramer's $V$ of .15 , small effect size. Massachusetts had the highest percentage (26\%) of Black male students who had AP exam scores that could potentially receive college credit; followed closely by Connecticut (17\%), Maryland (16\%), Florida (10\%) and Texas (9\%). Over $70 \%$ of Black male students in the five states examined in this study received AP scores for which they would not receive college credit.

Regarding the 2002 exam year, a statistically significant difference was revealed, $\chi^{2}(4)=26.19, P<.001$, Cramer's $V$ of .17, small effect size. Massachusetts had the highest percentage (26\%) of Black male students who had AP exam scores that could potentially receive college credit, followed by Connecticut (22\%), Maryland (21\%), Florida (13\%), and Texas (8\%). Over $70 \%$ of Black male students in the five states examined in this study received AP scores for which they would not receive college credit. Concerning the 2003 exam year, a statistically significant difference was yielded, $\chi^{2}(4)=$ 25.37, $P<.001$, Cramer's $V$ of .14, small effect size. Similar to the 2002 exam year, Massachusetts had the highest percentage (20\%) of Black male students who had AP exam scores that could potentially receive college credit, followed by Maryland (14\%), Connecticut (13\%), Texas (7\%), and Florida (6\%). Over $75 \%$ of Black male students in the five states examined in this study received AP scores for which they would not receive college credit.

In the 2004 exam year, a statistically significant difference was present, $\chi^{2}(4)=20.43, P<.001$, Cramer's $V$ of .12 , small effect size. Congruent with previous years, Massachusetts had the highest percentage (23\%) of Black male students who had AP exam scores that could potentially receive college credit, followed by Maryland (19\%), Connecticut (13\%), Florida (13\%), and Texas (9\%). Over $75 \%$ of Black male students in the five states examined in this study received AP scores for which they would not receive college credit. Concerning the 2005 exam year, a statistically significant difference was revealed, $\chi^{2}(4)=16.08, P=.003$, Cramer's $V$ of .10 , small effect size. In contrast to previous years, Connecticut had the highest percentage $(16 \%)$ of Black male students who had AP exam scores that could potentially receive college credit, followed by Massachusetts (15\%), Maryland (13\%), Florida (10\%), and
Texas (7\%). Over $80 \%$ of Black male students in each of the five states examined in this study received AP scores that are likely to yield no college credit.

For the 2006 exam year, a statistically significant difference was yielded, $\chi^{2}(4)=34.28, P<.001$, Cramer's $V$ of .14 , small effect size. Connecticut had the highest percentage (24\%) of Black male students who had AP exam scores that could potentially receive college credit; followed closely by Massachusetts (19\%), Maryland (14\%), Florida (11\%), and Texas (7\%). Again, over $75 \%$ of Black male students in the five states examined in this study received AP scores for which they would not receive college credit. With respect to the 2007 exam year, a statistically significant difference was revealed, $\chi^{2}(4)=12.34, P=.015$, Cramer's $V$ of .08 , trivial effect size. Massachusetts had the highest percentage (19\%) of Black male students who had AP exam scores that could potentially receive college credit, followed by Maryland (14\%), Florida (10\%), Texas (9\%), and Connecticut (8\%). Again, over $70 \%$ of Black male students in the five states examined in this study received AP scores for which they would not receive college credit.

Regarding the 2008 exam year, a statistically significant difference was revealed, $\chi^{2}(4)=62.30, P<.001$, Cramer's $V$ of .16, small effect size [44]. Similar to the 2002 exam year, Maryland had the highest percentage $(22 \%)$ of Black male students who had AP exam scores that could potentially receive college credit, followed by Massachusetts (17\%), Connecticut (9\%), Texas (8\%), and Florida (6\%). Over $75 \%$ of Black male students in the five states examined in this study received AP scores for which they would not receive college credit. Concerning the 2009 exam year, a statistically significant difference was yielded, $\chi^{2}(4)=79.92, P<.001$, Cramer's $V$ of .17 , small effect size. Massachusetts had the highest percentage $(25 \%)$ of Black male students who had AP exam scores that could potentially receive college credit, followed by Connecticut (19\%), Maryland (17\%), Texas (8\%), and Florida (6\%). Over $70 \%$ of Black male students in the five states examined in this study received AP scores for which they would not receive college credit.

For the 2010 exam year, a statistically significant difference was revealed, $\chi^{2}(4)=60.29, P<.001$, Cramer's $V$ of .13, small effect size. Massachusetts had the highest percentage $(23 \%)$ of Black male students who had AP exam scores that could potentially receive college credit, followed by Connecticut (19\%), Maryland (12\%), Texas (8\%), and Florida (7\%). Over $70 \%$ of Black male students in each of the five states examined in this study received AP scores that would not yield college credit. For the 2011 exam year, a statistically significant difference was yielded, $\chi^{2}(4)=66.99$, $P<.001$, Cramer's $V$ of .14, small effect size. Connecticut had the highest percentage (26.37\%) of Black male students who had AP exam scores that could potentially receive college credit, followed closely by Massachusetts (26.03\%), Maryland (16.29\%), Texas (9.94\%), and Florida (9.82\%). Over $70 \%$ of Black male students in the five states examined in this study received AP scores for which they would not receive college credit. With respect to the 2012 exam year, a statistically significant difference was revealed, $\chi^{2}(4)=46.27, P<.001$, 
Cramer's $V$ of .11, small effect size. Connecticut had the highest percentage $(25 \%)$ of Black male students who had AP exam scores that could potentially receive college credit, followed by Massachusetts (24\%), Maryland (15\%), Texas (11\%), and Florida (10\%). Over $70 \%$ of Black male students in the five states examined in this study received AP scores for which they would not receive college credit.

7.5. Results for Overall AP Exams. Focused upon in the fifth research question was a comparison of the overall AP exam scores of Black male students in Connecticut, Florida, Maryland, Massachusetts, and Texas, from 2001 through 2012. In the 2001 exam year, a statistically significant difference was revealed, $\chi^{2}(4)=69.15, P<.001$, Cramer's $V$ of .11 , small effect size. Massachusetts had the highest percentage (24\%) of Black male students who had AP exam scores that could potentially receive college credit, followed by Maryland (19\%), Connecticut (17\%), Florida (13\%), and Texas (11\%). Over $75 \%$ of Black male students in the five states examined in this study received AP scores for which they would not receive college credit.

Regarding the 2002 exam year, a statistically significant difference was yielded, $\chi^{2}(4)=68.24, P<.001$, Cramer's $V$ of .10 , small effect size. Massachusetts had the highest percentage (26\%) of Black male students who had AP exam scores that could potentially receive college credit, followed by Maryland (20\%), Connecticut (15.24\%), Florida (15.01\%), and Texas (12\%). Again, over $70 \%$ of Black male students in the five states examined in this study received AP scores for which they would not receive college credit. Regarding the 2003 exam year, a statistically significant difference was revealed, $\chi^{2}(4)=81.20, P<.001$, Cramer's $V$ of .10 , small effect size. Massachusetts had the highest percentage (23\%) of Black male students who had AP exam scores that could potentially receive college credit, followed by Connecticut (19\%), Maryland (17\%), Florida (12\%), and Texas (11\%). Again, over $75 \%$ of Black male students in the five states examined in this study received AP scores for which they would not receive college credit.

Concerning the 2004 exam year, a statistically significant difference was yielded, $\chi^{2}(4)=111.44, P<.001$, Cramer's $V$ of .11, small effect size. Congruent with previous years, Massachusetts had the highest percentage $(27 \%)$ of Black male students who had AP exam scores that could potentially receive college credit, followed by Maryland (19\%), Connecticut (18\%), Florida (14\%), and Texas (11\%). Again, over $70 \%$ of Black male students in the five states examined in this study received AP scores for which they would not receive college credit. Regarding the 2005 exam year, a statistically significant difference was revealed, $\chi^{2}(4)=103.00, P<.001$, Cramer's $V$ of .10 , small effect size. Massachusetts had the highest percentage $(21 \%)$ of Black male students who had AP exam scores that could potentially receive college credit, followed by Maryland (18\%), Connecticut (17\%), Florida (14\%), and Texas (10\%). Over $75 \%$ of Black male students in each of the five states examined in this study received AP scores that would not yield college credit.

For the 2006 exam year, a statistically significant difference was yielded, $\chi^{2}(4)=162.17, P<.001$, Cramer's $V$ of .11, small effect size. Massachusetts had the highest percentage (23\%) of Black male students who had AP exam scores that could potentially receive college credit; followed closely by Connecticut (19\%), Maryland (18\%), Florida (12\%), and Texas (10\%). Over $75 \%$ of Black male students in the five states examined in this study received AP scores for which they would not receive college credit. Regarding the 2007 exam year, a statistically significant difference was revealed, $\chi^{2}(4)=186.08, P<.001$, Cramer's $V$ of .11 , small effect size. Massachusetts had the highest percentage $(21 \%)$ of Black male students who had AP exam scores that could potentially receive college credit, followed by Connecticut (18\%), Maryland (18\%), Florida (11\%), and Texas (10\%). Again, over $75 \%$ of Black male students in the five states examined in this study received AP scores for which they would not receive college credit.

Concerning the 2008 exam year, a statistically significant difference was revealed, $\chi^{2}(4)=320.58, P<.001$, Cramer's $V$ of .12, small effect size. Massachusetts had the highest percentage $(23 \%)$ of Black male students who had AP exam scores that could potentially receive college credit, followed by Maryland (15.72\%), Connecticut (15.60\%), Texas (10\%), and Florida (8\%). Again, over $75 \%$ of Black male students in the five states examined in this study received AP scores for which they would not receive college credit. For the 2009 exam year, a statistically significant difference was present, $\chi^{2}(4)=247.73, P<.001$, Cramer's $V$ of .10 , small effect size. Massachusetts and Connecticut had the highest percentage (20\%) of Black male students who had AP exam scores that could potentially receive college credit, followed by Maryland (15\%), Texas (11\%), and Florida (9\%). Over $75 \%$ of Black male students in the five states examined in this study received AP scores for which they would not receive college credit.

With respect to the 2010 exam year, a statistically significant difference was revealed, $\chi^{2}(4)=244.90, P<.001$, Cramer's $V$ of .09 , trivial/small effect size. Massachusetts had the highest percentage (19\%) of Black male students who had AP exam scores that could potentially receive college credit, followed by Connecticut (16\%), Maryland (13\%), Texas (10\%), and Florida (8\%). Over $80 \%$ of Black male students in each of the five states examined in this study received AP scores that are likely to yield no college credit. For the 2011 exam year, a statistically significant difference was yielded, $\chi^{2}(4)=121.43$, $P<.001$, Cramer's $V$ of .07 , trivial effect size. Connecticut had the highest percentage (19\%) of Black male students who had AP exam scores that could potentially receive college credit, followed by Massachusetts (17\%), Maryland (14\%), Florida (14\%), and Texas (10\%). Over $80 \%$ of Black male students in the five states examined in this study received AP scores for which they would not receive college credit. With respect to the 2012 exam year, a statistically significant difference was yielded, $\chi^{2}(4)=246.81, P<.001$, Cramer's $V$ of .09, trivial/small effect size. Massachusetts had the highest percentage $(22 \%)$ of Black male students who had AP exam scores that could potentially receive college credit, followed by Connecticut (16.07\%), Maryland (15.79\%), Texas (12\%), and Florida (10\%). Over $75 \%$ of Black male students in the 
five states examined in this study received AP scores for which they would not receive college credit.

7.6. Trends in AP Exam Performance. The sixth research question involved an analysis of related trends in the AP English Language and Composition exam performance for Black male students in Connecticut, Florida, Maryland, Massachusetts, and Texas, 2001 through 2012. For the years analyzed, eight of the comparisons for AP English Language and Composition exam scores were statistically significant. As a result, differences were present by state residency for AP exam scores achieved by Black male students. Black male students in Connecticut were better prepared to attain an AP English Language and Composition score that could result in receiving college credit as compared to students in Florida, Maryland, Massachusetts, and Texas. Black male students in Texas and Florida were the least prepared to achieve such an advantage.

In the seventh research question, the emphasis was on trends in the $\mathrm{AP}$ Calculus $\mathrm{AB}$ exam performance of Black male students in Connecticut, Florida, Maryland, Massachusetts, and Texas for 2001 through 2012. Only two of the comparisons for AP Calculus AB exam scores were statistically significant, 2006 and 2009, with effect sizes of .11 and .09, respectively. No more than $40 \%$ of the Black male students in these states achieved an AP score of 4 or 5 . As such, the academic preparation of Black male AP Calculus $A B$ examinees was insufficient in all of these states.

The eighth research question encompassed trends in the AP Biology exam performance of Black male students in Connecticut, Florida, Maryland, Massachusetts, and Texas for the 2001 through the 2012 exam years. Four of the 12 comparisons for AP Biology exam scores were statistically significant (i.e., 2002, 2008, 2009, and 2012). In 2008, Black male examinees in Massachusetts and Texas had the same percentage of scores that would yield the potential for receiving college credit - the only instance in this study where students from Texas achieved the highest percentage of Black male students who earned an AP score of 4 or 5 as compared to Black male students from Connecticut, Florida, Maryland, and Massachusetts.

The ninth research question required an analysis of trends in the AP US History exam performance of Black male students in Connecticut, Florida, Maryland, Massachusetts, and Texas for the 2001 through the 2012 exam years. In contrast to the previous research questions, all of the comparisons for the AP US History exam scores were statistically significant. Differences by state residency within the distribution of AP exam scores achieved by Black male students were clearly present. Black male student performance from each of these states was different between the states. Regardless of the differences between the states, Black male students were just as ill-prepared in one state as they were in one of the other states. Specifically, no more than $26 \%$ of the Black male AP US History examinees from any state achieved a score greater than 3 between 2001 and 2012 .

Addressed in the tenth and final research question were trends in the overall AP exam performance of Black male students in Connecticut, Florida, Maryland, Massachusetts,

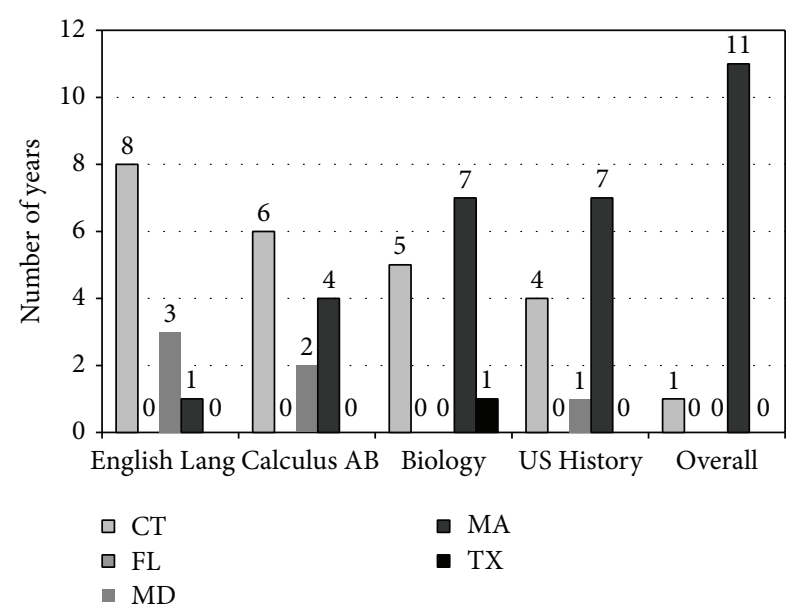

FIGURE 1: A summary of the number of years in which Black male students in Connecticut, Florida, Maryland, Massachusetts, and Texas achieved the highest percentage of students who earned an AP exam of 4 or 5 between 2001 and 2012 .

and Texas for the 2001 through the 2012 exam years. Congruent with the results for the AP US History Exam, each of the comparisons for the overall AP examination scores between 2001 and 2012 was statistically significant. Clear differences by state residency were present within the distribution of overall AP exam scores of Black male students. Overall Black male students in Massachusetts were better prepared for AP examinations as compared to Black male students in the other four states whose data were analyzed herein.

Delineated in Figure 1 is a summary of the number of years in which each state had the highest percentage of Black male students who earned an AP exam score of 4 or 5 during the 2001 through 2012 exam years. The purpose of Figure 1 is to provide a graphical representation of the frequency in which states had the highest percentage of achieving Black male students as it relates to the AP exams addressed within this study. The data included in Figure 1 represent the fact that of the exams analyzed from 2001 through 2012, Black male students from Massachusetts achieved the highest percentage of students with an AP score of 4 or 5 as compared to Black male students from Connecticut, Florida, Maryland, Massachusetts, and Texas.

Alternatively, Figure 2 includes a summary of the number of years in which each state had the highest percentage of Black male students who earned an AP exam score of 3 or less during the 2001 through 2012 exam years. Exam scores less than 4 may not afford students the potential for earning college credit. As such, the frequency in which a state appears in Figure 2 is indicative of a lack of student achievement as it relates to the AP exams analyzed within this study. Fundamentally, the aim of Figure 2 is to provide a graphical representation of the frequency in which states had the highest percentage of Black male students who achieved unacceptable scores on the respective AP exams addressed within this study. 


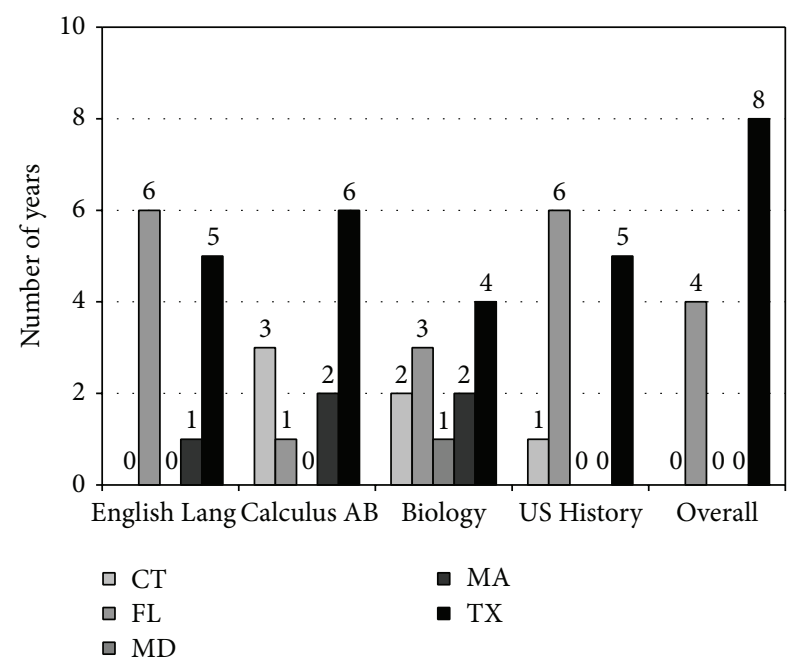

FIGURE 2: A summary of the number of years in which Black male students in Connecticut, Florida, Maryland, Massachusetts, and Texas achieved the highest percentage of students who earned an AP exam of 3 or lower between 2001 and 2012.

\section{Discussion}

The idea that Black males are continuously at the bottom of the academic spectrum as it relates to high school completion, college readiness, and college completion is a reality that must be addressed if educators and policy makers truly want to improve upon the American educational system [4, 10, 4548]. A failure to do so will result in the continued existence of poverty, crime, and dysfunctional families within the Black community. Indeed, the implications for the stated results are far reaching and can affect every facet of life. Similarly, the assertions that exposure to and success within AP courses are one avenue toward ensuring the college-readiness of high school graduates $[2,10,49-52]$ deserve attention to the lack of equity within the AP programs across the nation. Specifically, Black male students have continuously failed to achieve the requisite scores on AP exams at the same rate as their Asian, Hispanic, and White counterparts $[1,10,27,30,53]$.

8.1. Summary of Black Male Student Performance Across the States. A summarization of student achievement on select AP exams across the states included within this study yields evidence of the fact (reword this) that Black male students from Massachusetts consistently outperformed Black male students from Connecticut, Florida, Maryland, and Texas. Specifically, Massachusetts was the highest performing state in three of the five AP exam categories analyzed (i.e., AP Biology, AP United States History, and Overall exams) by virtue of it being the state with the highest percentage of Black male students who earned an AP exam score of 4 or 5 during the 2001 through 2012 exam years. Conversely, Texas was the state with the highest percentage of Black male students who earned an AP exam score of 3 or less during the 2001 through 2012 exam years, thereby earning Texas the distinction as the lowest performing state as it relates to this study.
With regard to the AP English Language and Composition exam, Connecticut was the highest performing state while Florida was the lowest performing state. Black male students in Connecticut had the highest percentages of scores that could yield potential for college credit for 8 of the 12 years analyzed (i.e., 2001, 2003, 2005, 2006, 2007, 2009, 2011, and 2012) as compared to students from Florida, Maryland, Massachusetts, and Texas. Conversely, the Black male students in Florida had the highest percentages of scores that could not yield potential for college credit for half of the years of data analyzed herein (i.e., 2002, 2008, 2009, 2010, 2011, and 2012). Similarly, the highest performing state concerning AP Calculus $\mathrm{AB}$ was Connecticut where Black male examinees outperformed their peers in the other states examined for 6 of the 12 years examined (i.e., 2001, 2004, $2008,2009,2010$, and 2011). In contrast, the state with the lowest performing measures in $\mathrm{AP}$ Calculus $\mathrm{AB}$ was Texas; whereby Black male students failed to achieve a score that could yield them potential for college credit for half of the 12 years examined (i.e., 2001, 2003, 2004, 2006 2007, and 2009). Furthermore, the average percentage of Black male students from Texas who earned a score of 4 or 5 on the Calculus $A B$ exam was $17.63 \%$, the lowest among all of the states studied.

Though Connecticut maintained the distinction as the state with the highest percentage of Black male students who achieved AP exam scores of 4 or 5 for the aforementioned exam categories, Massachusetts maintained such a distinction for the remaining 3 exam categories analyzed. Regarding the AP Biology, AP United States History, and Overall AP exams, Black male examinees in Massachusetts outperformed their peers in Connecticut for 7 years, 7 years, and 11 years, respectively. Conversely, Texas possessed the highest percentage of Black male students who failed to achieve AP exam scores of 4 or 5 on the AP Biology and Overall AP exams for 4 years (i.e., 2001, 2002, 2007, and 2011) and 8 years (i.e., 2001, 2002, 2003, 2004, 2005, 2006, 2007, and 2011), respectively, while Black male students in Florida had higher percentages of failing to achieve AP exam scores of 4 or 5 on the AP US History exam for 6 of the years analyzed. Additionally, only 1 out of every 10 Black male student participants achieved a favorable score on the AP U.S. History exam during 6 of the 12 years analyzed.

8.2. Implications for Policy. The systemic praxes present within school districts across the nation illustrate, we believe, the necessity of concentrating on college readiness, gender equity, and racial equity related to the AP program. In accordance with Haddix's [54] recommendations, a state and national level of oversight of AP programs are warranted to ensure the presence of a consistent implementation and evaluation system that would culminate in increased accountability among state educational leaders. Such accountability, coupled with Ladson-Billings' [55] proposition that researchers conduct investigations focused upon the extent to which existing achievement gaps are caused by experiences related to low school funding, income-levels, or stigmas placed upon Black students, would provide the required academic infrastructure where equitable student achievement can occur among students from all ethnic groups. 
Transformational changes that directly impact the culture and climate of a school begin with the attitudes and beliefs of educators related to Black students, in general, and Black males, in particular, and their ability to learn $[6,56]$. We encourage researchers to conduct studies grounded in critical race theory and organizational management as they pertain to college readiness among Black students. Undeniably, White privilege is established throughout every facet of society including instructional planning. Specifically, biased teacher attitudes and perceptions guide the development of curricular and pedagogical practices geared toward White, middle-class students and said planning has been supported by biased educational policies that serve to privilege Whites while oppressing people of color [57]. Given this fact, the acknowledgement of White privilege by educators must occur as leaders form professional development that guides teachers, counselors, and school administrators toward a paradigm shift regarding their approach to teaching Black students, in general, and Black males, in particular. Additionally, it is recommended that the College Board incorporates research-based instructional strategies and pedagogical approaches into the current body of AP professional development sessions underwritten by the College Board. Indeed, professional development measures that incorporate the counsel of the contributors to the College Board's [9] study alongside the selection of culturally inclusive course materials will result in a learning environment where Black male students learn and thrive as they embody their cultural identities beyond what is safe and acceptable to mainstream White America.

Gosa and Alexander [58] asserted that ignoring race will not eliminate its existence as a stratifying mechanism but will impede the active exploration for corrective remedies and progress toward a more just society. As such, when considering the implications of policy related to parental involvement, teacher attitudes, and curricular and pedagogical practices within AP classrooms, it is important to note that the achievement gap between White and non-White students, especially Black male students, will not vanish without the honest acknowledgement that race still matters.

Finally, an in-depth analysis of the credit-granting practices of colleges and universities based upon AP exam performance is needed if equity is the desired result. Students are encouraged to take AP courses and examinations with the hope of earning college credit if the student achieves an AP exam score of 3 or higher. To the contrary, universities set independent policies for awarding such credit eliminating the assurance that an AP score of 3 will guarantee the receipt of college credit. In fact, not every AP exam score of 3 is accepted at every college and university for credit. In essence, students who achieve a score of 4 or higher only earn the potential for receiving college credit. As such, a universal policy that sets the minimum AP exam score for which college credit will be granted would benefit students, who take AP exams for the sole purpose of earning college credit across the nation. Moreover, empirical comparisons of Black male with Black female student performance would further support efforts toward increasing equity and diversity at colleges and universities.
8.3. Recommendations for Future Research. This investigation constitutes the first study of its kind in which AP exam performance among Black male students across various states for multiple years was analyzed. Davis [40] analyzed the performance of Black students in Texas, New York, and Florida on select AP examinations. Corresponding findings between this study and Davis' [40] research is an impetus for replicating this study to compare the AP exam performance of Black male students in other states. Moreover, a comparison of Black male student performance on all AP exams across the states addressed within this study is suggested to ascertain differences within specific content areas. Similarly, an extension of this study that compares AP exam performance between Black male and Black female students across the states addressed within this study to ascertain the presence of gender differences is recommended. Additionally, in consideration for the influence of economies of scale as noted by Slate and Jones [59] on the outcome of the data, a replication of this analysis to compare the AP exam performance of Black male students in states with similar population sizes is warranted.

The results of this study yielded evidence that Black male students in Massachusetts and Connecticut consistently outperformed Black male students in Maryland, Florida, and Texas. Moreover, the data provided statistical evidence that Black male students in Texas consistently achieved the poorest exam scores. Given the findings of Fitzgerald et al's [60] recent investigation of differences in completion rates in Texas high schools among White, Black, and Hispanic students and their subsequent suggestion that the "current educational policies in Texas need to be re-reexamined" (p. 7), an in-depth analysis into the policies and practices related to AP programs in Texas is appropriate. Conversely, the findings of this study provide evidence that Black male students in Maryland are not performing at stellar rates on AP exams. Therefore, the absence of equity is present within Maryland schools and enquiries into the curricular and pedagogical practices, with an emphasis on non-White students in Maryland, and is highly recommended due to the recent accolades Maryland has received from the College Board $[1,10,30,53]$.

To be sure, programmatic policies and practices in and of themselves are not sole reasons for poor academic performance. Moore and Slate [43] asserted that comparing the academic performance of White and non-White high school students is not always indicative of inappropriate practices or policies. Instead, poor academic performance among nonWhite students is oftentimes the result of ill-prepared teachers [61]. Accordingly, a qualitative focus on the attitudes and perceptions of Black males and their AP teachers is warranted for a more in-depth examination of the results presented.

\section{Conclusion}

The purpose of this study was to analyze the extent to which differences in student performance were present between Black males in Connecticut, Florida, Maryland, Massachusetts, and Texas on select AP examinations (i.e., English Language and Composition, Calculus AB, Biology, and 
United States History) from 2001 through 2012 exam years, a significant indicator of increasing equity while increasing enrollment and participation. Equally, this study is significant in the context of student achievement on AP examinations, which has been regarded as a reliable indicator of collegereadiness. Contrary to previous studies, student performance grounded in the student's propensity to receive college credit based upon their AP exam score was analyzed. Patterson and Ewing [62] reported that generally an AP score of 3 was the most common minimum AP Exam score required for credit. However, current trends among colleges and universities involve the awarding of such credit when students have achieved an AP score of 4 or 5 on select exams, as opposed to the conventional practice of receiving college credit for AP scores of 3 or higher.

An analysis of AP examination performance between Black males in Connecticut, Florida, Maryland, Massachusetts, and Texas may serve as a springboard for a more in-depth critique of the specific strategies applied within each of the included states pertaining to recruitment and student achievement for Black male students. Connecticut, Florida, Maryland, and Massachusetts were chosen due to each state's position among the top 10 states in the nation where record percentages of students scored an AP score of 3 or higher for the past six years. Texas was chosen for inclusion within this study due to the reported gains that Texas school districts have attained in relation to student achievement on AP exams, a feat worthy of analysis due to the size of the student population in Texas.

The findings of this study may be interpreted to denote that significant increases in student achievement among AP students in the states analyzed are not indicative of an equal increase in student achievement for Black male AP students. Indeed, at least $65 \%$ of the Black male population for the AP exams included in this study from 2001 through 2012 did not achieve an AP score that could yield them the propensity to receive college credit based upon their AP exam scores. Specifically, evidence of an achievement gap was present for Black males in Maryland, a state that has been lauded as the top AP state in the nation $[1,10,30]$. In fact, pertaining to this study, Black male students from Massachusetts consistently outperformed Black male students from Maryland.

Jackson and Moore III [17] asserted that the existing body of knowledge related to the educational experiences of Black males is limited and disjointed. This endeavor warrants inclusion in the existing research literature in efforts to eliminate the death in academic literature related to Black male students and achievement. As such, we hope that this work fosters transformational measures within school districts specifically designed to assure the success of Black males.

\section{Conflict of Interests}

We, the authors of this article, do declare that there is no conflict of interest regarding the publication of this article.

\section{References}

[1] G. W. Moore and J. R. Slate, "A multi-year analysis of Asian gender differences on advanced placement exams,"
International Journal of Educational Leadership Preparation, vol. 6, no. 4, 2011, http://cnx.org/contents/2e40891c-58dd-43f5b8c8-9e1874elca15@1.

[2] K. Klopfenstein, "Advanced Placement: do minorities have equal opportunity?" Economics of Education Review, vol. 23, no. 2, pp. 115-131, 2004.

[3] G. W. Moore and J. R. Slate, "A multi-year analysis of Asian gender differences on Advanced Placement exams," International Journal of Educational Leadership Preparation, vol. 6, no. 4, 2012.

[4] College Board, College Completion Agenda Progress Report 2011, 2011, http://advocacy.collegeboard.org/.

[5] Education Week, “Achievement gap," 2011, http://www.edweek .org/ew/issues/achievement-gap.

[6] S. Lewis, C. Simon, R. Uzzell, A. Howitz, and M. Casserly, A Call for Change: The Social and Educational Factors Contributing to the Outcomes of Black Males in Urban Schools, The Council of the Great City Schools, Washington, DC, USA, 2010.

[7] X. Fan, "Parental involvement and students' academic achievement: a growth modeling analysis," Journal of Experimental Education, vol. 70, no. 1, pp. 27-61, 2001.

[8] Schott Foundation for Public Education, "Yes we can: The 2010 Schott 50 state report on Black males in public education," 2010, http://Blackboysreport.org/bbreport.pdf.

[9] College Board, "The educational crisis facing young men of color," 2010, http://advocacy.collegeboard.org/sites/default/ files/educational-crisis-facing-young-men-of-color.pdf.

[10] College Board, Ninth Annual AP Report to the Nation, 2013, http://media.collegeboard.com/digitalServices/pdf/ap/rtn/9thannual/9th-annual-ap-report-single-page.pdf.

[11] K. Klopfenstein, "The advanced placement expansion of the 1990s: how did traditionally underserved students fare?" Education Policy Analysis Archives, vol. 12, no. 68, 2004, http://epaa .asu.edu/ojs/index.php/epaa/article/view/223/349.

[12] G. W. Moore and J. R. Slate, "Who's taking the Advanced Placement courses and how are they doing: a statewide two-year study," The High School Journal, vol. 92, no. 1, pp. 57-67, 2008.

[13] M. Corra, J. S. Carter, and S. K. Carter, "The interactive impact of race and gender on high school advanced course enrollment," The Journal of Negro Education, vol. 80, no. 1, pp. 33-46, 2011.

[14] M. Fultz and A. Brown, "Historical perspectives on African American males as subjects of education policy," The American Behavioral Scientist, vol. 51, no. 7, pp. 854-871, 2008.

[15] A. M. Garibaldi, "The educational experiences of Black males: the early years," Challenge: A Journal of Research on Black Men, vol. 2, pp. 36-49, 1991.

[16] R. E. Hallett and K. M. Venegas, "Is increased access enough? Advanced placement courses, quality, and success in lowincome urban schools," Journal for the Education of the Gifted, vol. 34, no. 3, pp. 468-487, 2011.

[17] J. F. L. Jackson and J. L. Moore III, "African American males in education: endangered or ignored?" Teachers College Record, vol. 108, no. 2, pp. 201-205, 2006.

[18] P. A. Noguera, "Reconsidering the crisis of the Black male in America," Social Justice, vol. 24, no. 2, pp. 147-164, 1997.

[19] P. L. Carter, “"Black” cultural capital, status positioning, and schooling conflicts for low-income African American youth," Social Problems, vol. 50, no. 1, pp. 136-155, 2003.

[20] R. D. Reason and N. J. Evans, "The complicated realities of whiteness: from color blind to racially cognizant," New Directions for Student Services, vol. 120, pp. 67-74, 2007. 
[21] A. Shiu, T. Kettler, and S. K. Johnsen, "Social effects of Hispanic students enrolled in an AP class in middle school," Journal of Advanced Academics, vol. 21, no. 1, pp. 58-82, 2009.

[22] T. L. Strayhorn, "Different folks, different hopes: the Educational aspirations of Black males in urban, suburban, and rural high schools," Urban Education, vol. 44, no. 6, pp. 710-731, 2009.

[23] S. R. Harper, Black Male Students at Public Flagship Universities in the US: Status, Trends and Implications for Policy and Practice, Joint Center for Political and Economic Studies Health Policy Institute, Washington, DC, USA, 2006.

[24] D. U. Patton, M. E. Woolley, and J. S. Hong, "Exposure to violence, student fear, and low academic achievement: African American males in the critical transition to high school," Children and Youth Services Review, vol. 34, no. 2, pp. 388-395, 2012.

[25] M. Planty, W. J. Hussar, and T. D. Snyder, Condition of Education 2009, National Center for Education Statistics, Washington, DC, USA, 2009.

[26] E. Rothschild, "Four decades of the Advanced Placement program," The History Teacher, vol. 32, no. 2, pp. 175-206, 1999.

[27] College Board, "Fifth annual AP report to the Nation: Texas Supplement," http://professionals.collegeboard.com/profdownload/Texas-AP-Report-2009.pdf.

[28] W. G. Tierney and J. Alexander, "A university helps prepare low income youths for college: tracking school success," Journal of Higher Education, vol. 72, no. 2, pp. 205-225, 2001.

[29] College Board, The Educational Experience of Young Men of Color: Capturing the Student Voice, 2010, http://youngmenofcolor.collegeboard.org/sites/default/files/downloads/EEYMC-StudentVoice.pdf.

[30] College Board, Seventh annual AP report to the Nation, 2011, http://apreport.collegeboard.org/?excmpid=CBF13-ED-1aprtn.

[31] C. M. Davis, S. A. Joyner, and J. R. Slate, "Differences in advanced placement exam results for Black students across three states," E-International Journal of Educational Research, vol. 2, no. 2, pp. 87-102, 2011.

[32] J. Schneider, "Privilege, equity, and the advanced placement program: tug of war," Journal of Curriculum Studies, vol. 41, no. 6, pp. 813-831, 2009.

[33] D. G. Solórzano and A. Ornelas, "A critical race analysis of advanced placement classes: a case of educational inequality," Journal of Latinos and Education, vol. 1, no. 4, pp. 215-229, 2002.

[34] J. D. Taliaferro and J. T. DeCuir-Gunby, "African American educators' perspectives on the advanced placement opportunity gap," Urban Review, vol. 40, no. 2, pp. 164-185, 2008.

[35] J. N. Wyatt and K. D. Mattern, Low-SES Students and College Outcomes: The Role of AP Fee Reductions, College Board, New York, NY, USA, 2011.

[36] National Center for Education Statistics, "The condition of education 2007 (NCES 2007-066),” 2007, http://nces.ed.gov/ pubs2007/2007064_SpecialAnalysis.pdf.

[37] L. Hargrove, D. Godin, and B. Dodd, College Outcomes: Comparisons by AP and Non-AP High School Experiences, College Board, New York, NY, USA, 2008.

[38] G. Ladson-Billings, "Just what is critical race theory and what's it doing in a nice field like education?" International Journal of Qualitative Studies in Education, vol. 11, no. 1, pp. 7-24, 1998.

[39] B. Johnson and L. Christensen, Educational Research: Quantitative, Qualitative, and Mixed Approaches, Sage, Thousand Oaks, Calif, USA, 3rd edition, 2008.
[40] C. M. Davis, A multi-year comparison of advanced placement scores for black students in Texas, New York, and Florida [Unpublished doctoral dissertation], Sam Houston State University, Huntsville, Tex, USA, 2013.

[41] B. M. Koch, A comparison of Advanced Placement scores for Hispanic students from California, Texas, and Arizona [ProQuest dissertations and theses], 2012.

[42] G. W. Moore, J. P. Combs, and J. R. Slate, "Advanced placement exams participation and performance: a national study of gender differences," e-International Journal of Educational Research, vol. 3, no. 3, pp. 18-32, 2012.

[43] G. W. Moore and J. R. Slate, "Advanced placement courses and American Indian performance," American Secondary Education, vol. 38, no. 2, pp. 73-94, 2010.

[44] J. Cohen, Statistical Power Analysis for the Behavioral Sciences, Lawrence Erlbaum Associates, Hillsdale, NJ, USA, 1988.

[45] P. A. Noguera, The Trouble with Black Boys: And Other Reflections on Race, Equity and the Future of Public Education, JosseyBass, Hoboken, NJ, USA, 2009.

[46] L. Darling-Hammond, "New standards and old inequalities: school reform and the education of African American students," The Journal of Negro Education, vol. 69, pp. 263-287, 2000.

[47] The Kaiser Family Foundation, Young African American Men in the United States, 2006, http://www.kff.org/minorityhealth/ upload/7541.pdf.

[48] J. Kozol, The Shame of the Nation: The Restoration of Apartheid Schooling in America, Crown, New York, NY, USA, 2005.

[49] W. Barnes and J. R. Slate, "College-readiness: the current state of affairs," Academic Leadership: The Online Journal, vol. 8, no. 4, 2010, http://www.academicleadership.org/article/college-readiness-the-current-state-of-affairs.

[50] K. Klopfenstein and M. Kathleen Thomas, "The link between advanced placement experience and early college success," Southern Economic Journal, vol. 75, no. 3, pp. 873-891, 2009.

[51] G. W. Moore, S. A. Joyner, C. Martinez-Garcia, and J. R. Slate, "College-readiness of Asian American students and of white students: a statewide study," International Journal of University Teaching and Faculty Development, vol. 2, no. 4, pp. 235-244, 2011.

[52] W. Barnes and J. R. Slate, "College-readiness is not one-size-fitsall," Current Issues in Education, vol. 16, no. 1, 2013.

[53] College Board, "Sixth annual AP report to the Nation," Retrieved from EBSCO Discovery Service, 2010.

[54] M. S. Haddix, The role of judicial decisions on access and equity: A case study of Daniel v. State of California (1999) and the AP Challenge Grant, Senate Bill 1689 (2000) [Doctoral dissertation], University of Southern California, 2010.

[55] G. Ladson-Billings, "Pushing past the achievement gap: an essay on the language of deficit," Journal of Negro Education, vol. 76, no. 3, pp. 316-323, 2007.

[56] G. Ladson-Billings, The Dreamkeepers: Successful Teachers of African American Children, Jossey-Bass, San Francisco, Calif, USA, 1994.

[57] P. McIntosh, "White privilege: unpacking the invisible knapsack," Independent School, vol. 49, no. 2, pp. 31-35, 1990.

[58] T. L. Gosa and K. L. Alexander, "Family (Dis) advantage and the educational prospects of better off African American youth: how race still matters," Teachers College Record, vol. 109, no. 2, pp. 285-321, 2007.

[59] J. R. Slate and C. H. Jones, "Effects of school size: a review of the literature with recommendations," Essays in Education, vol. 13, 2005, http://www.usca.edu/essays/vol132005/slate.pdf. 
[60] K. Fitzgerald, T. Gordon, A. Canty, R. E. Stitt, A. J. Onwuegbuzie, and R. K. Frels, "Ethnic differences in completion rates as a function of school size in Texas high schools," The Journal of At-Risk Issues, vol. 17, no. 2, pp. 1-10, 2012.

[61] C. Talbert-Johnson, "Structural inequities and the achievement gap in urban schools," Education and Urban Society, vol. 37, no. 1, pp. 22-36, 2004.

[62] B. F. Patterson and M. Ewing, Validating the Use of AP Exam Scores for College Course Placement, College Board, New York, NY, USA, 2013, http://research.collegeboard.org/sites/ default/files/publications/2013/7/researchreport-2013-2-validating-AP-exam-scores-college-course-placement.pdf. 

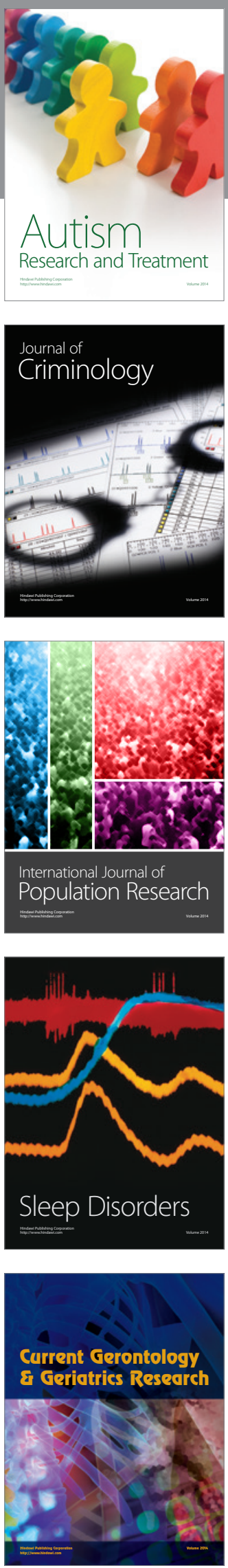
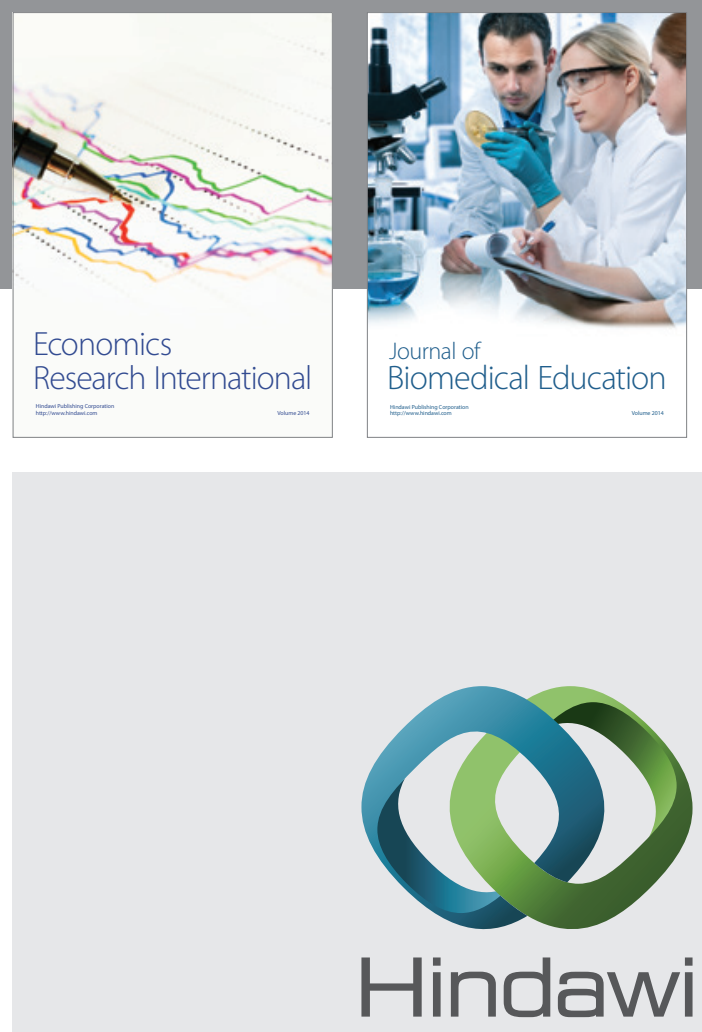

Submit your manuscripts at

http://www.hindawi.com
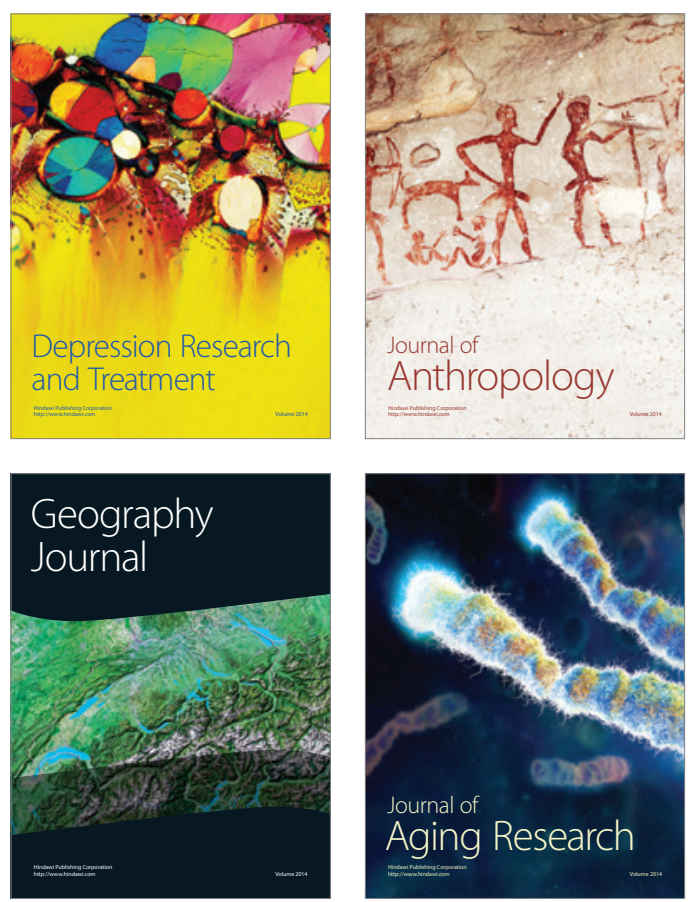
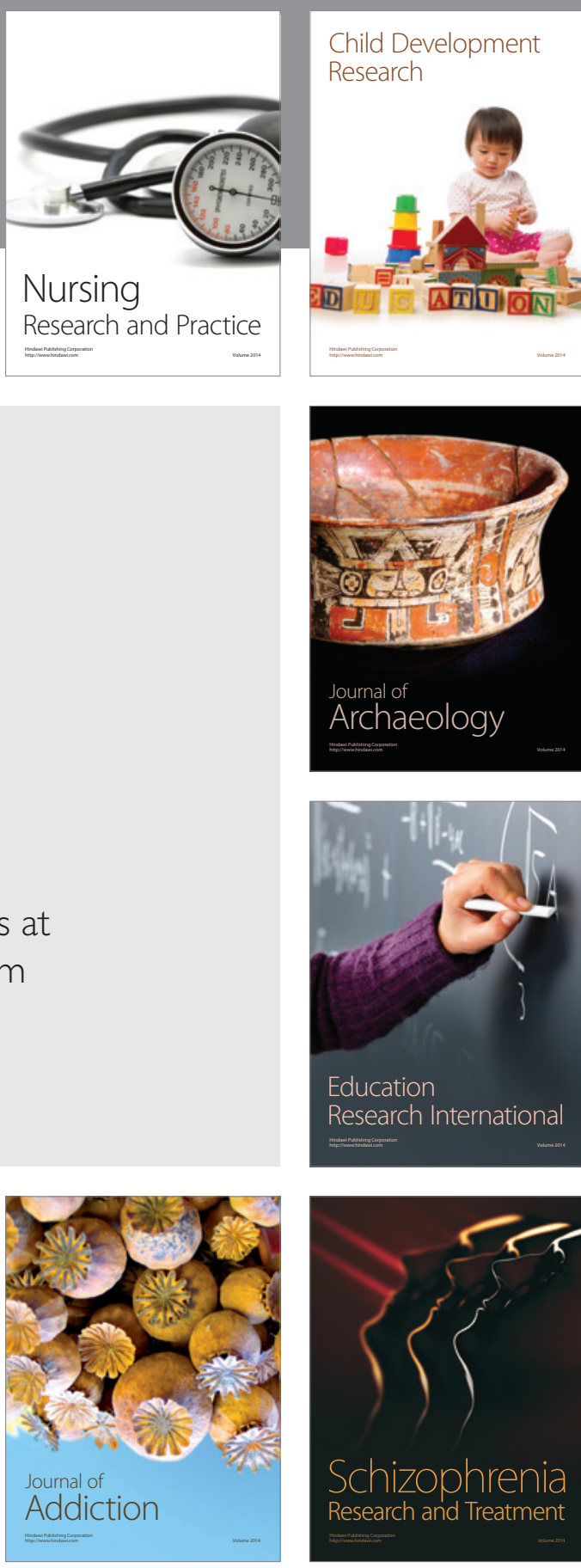

(D)
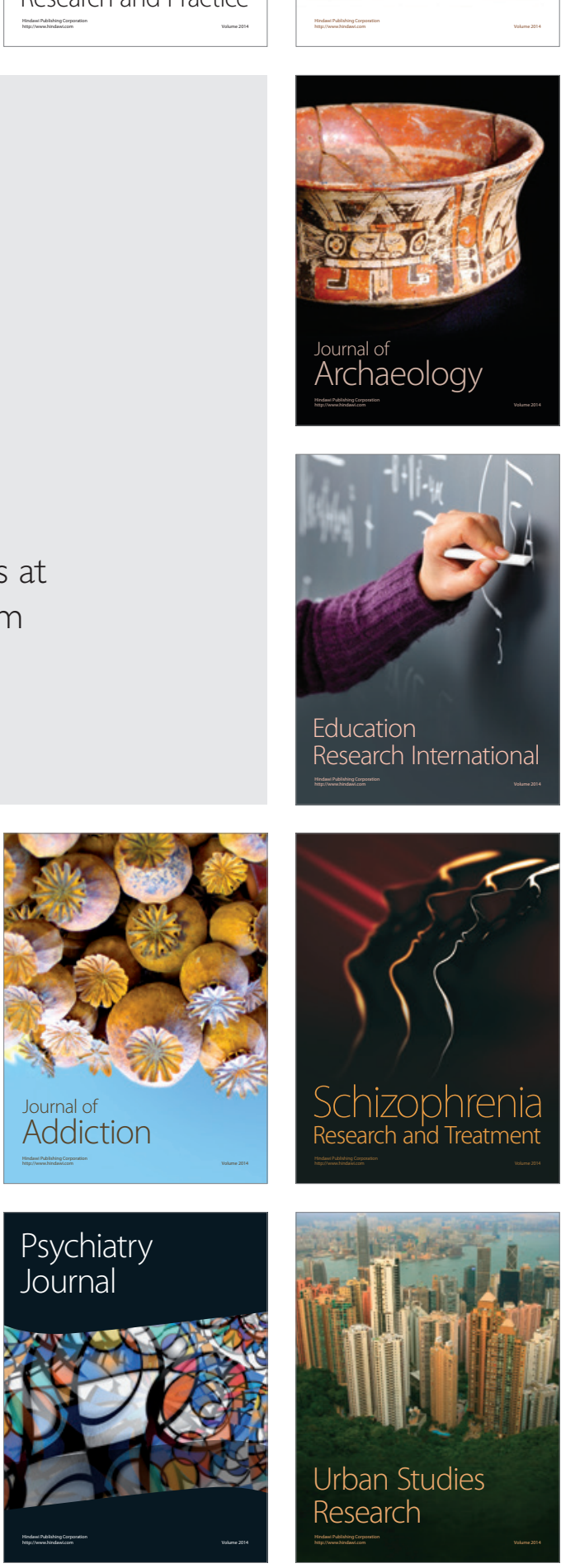